\title{
PENGARUH TEMAN SEBAYA TERHADAP PERILAKU MENYIMPANG SISWA KELAS X SMK SWASTA SATRIA BINJAI TAHUN PELAJARAN $2017 / 2018$.
}

\author{
Sari Wardani Simarmata, Fahmi Ilyas Karo Karo \\ Penulis adalah Dosen Sekolah Tinggi Keguruan dan Ilmu Pendidikan (STKIP) \\ Perguruan Tinggi Budidaya Binjai
}

\begin{abstract}
Purpose of this research is to know the influence of peers on the deviant behavior of class X SMK Binjai Satria Private Lessons Year 2017/2018 .Populasi fifty students, based on the opinions Suharsimi Arikunto when the subject is less than 100 better taken all that research is a population study, based on the opinion of the samples will be taken from the number populasisehingga entire sample in this study amounted to 50 students. This research is a quantitative research. The questionnaire results of peers obtained from the respondents have obtained average value / mean of 52. Hasil questionnaire deviant behavior obtained from the respondents have obtained average value / mean of 59,5. Setelah know that the data collected is valid, then calculation is then performed to test the normality of the data, from the calculation of the normality test has been known that the samples obtained normal distribution, as well as statistical testing was performed using simple linear regression analysis with the testing criteria to test the linearity and regresi.Pada equation significance test research hypotheses, find that the working hypothesis or Ha received $r$ valuecalculated at 0.314 and rtable at 0.284 , Because rcount $>$ rtable $(0.314>0.284)$, we can conclude Ha accepted, that there are Influence Peers Against Deviant Behavior Class X SMK Private Satria Binjai Academic Year 2017/2018
\end{abstract}

Keywords: $P$ Notwithstanding rilaku, Peer

\section{PENDAHULUAN}

Masa remaja merupakan fase dimana siswa masih dalam tahapan pengenalan diri. Dalam masa ini tidak sedikit remaja yang mengalami kegoncangan yang menyebabkan munculnyaemosional yang belum stabil sehingga mudah melakukan pelanggaran terhadap norma-norma dalam masyarakat.Remaja sebagai manusia yang sedang tumbuh dan berkembang terus melakukan interaksi sosial baik antara remaja maupun terhadap lingkungan lain. Melalui proses adaptasi, remaja mendapatkan pengakuan sebagai anggota kelompok baru yang ada dalam lingkungan sekitarnya. Remaja pun rela menganut kebiasaan-kebiasaan yang berlaku dalam suatu kelompok remaja. Dalam pergaulan remaja, kebutuhan untuk dapat diterima bagi setiap individu merupakan suatu hal yang sangat mutlak sebagai makhluk sosial. Setiap anak yang memasuki usia remaja akan dihadapkan pada permasalahan penyesuaian sosial, yang 
diantaranya adalah problematika pergaulan teman sebaya. Pembentukan sikap, tingkah laku dan perilaku sosial remaja banyak ditentukan oleh pengaruh lingkungan ataupun teman-teman sebaya. Apabila lingkungan sosial itu menfasilitasi atau memberikan peluang terhadap remaja secara positif, maka remaja akan mencapai perkembangan sosial secara matang. Dan apabila lingkungan sosial memberikan peluang secara negatif terhadap remaja, maka perkembangan sosial remaja akan terhambat.Pengaruh lingkungan diawali dengan pergaulan dengan teman. Pada usia 9-15 tahun hubungan perkawanan merupakan hubungan yang akrab yang diikat oleh minat yang sama, kepentingan bersama, dan saling membagi perasaan, saling tolong menolong untuk memecahkan masalah bersama. Peran teman sebaya dalam pergaulan remaja menjadi sangat menonjol.Menurut Sarwono, hal ini sejalan dengan meningkatnya minat individu dalam persahabatan serta keikut sertaan dalam kelompok.Kelompok teman sebaya juga menjadi suatu komunitas belajar di mana terjadi pembentukan peran dan standar sosial yang berhubungan dengan pekerjaan dan prestasi.

Dalam prosesnya, sosialisasi terjadi melalui "conditioning” oleh lingkungan yang menyebabkan individu mempelajari pola kebudayaan yang fundamental seperti bahasa, cara berjalan, duduk, makan, apa yang dimakan, berkelakuan sopan, mengembangkan sikap yang dianut dalam masyarakat seperti sikap terhadap agama, orang yang lebih tua, pekerjaan, reaksi, dan segala sesuatu yang perlu bagi warga masyarakat yang baik. Belajar norma-norma kebudayaan pada mulanya banyak terjadi dirumah dan sekitar, kemudian di sekolah, bioskop, televisi dan lingkungan lain.Di samping itu ada lagi bentuk pelajaran sosial yang bersifat pribadi misalnya seseorang suka atau tidak suka kepada orang yang meminta-minta, pemain kartu, dan sebagainya. Pengalaman serupa itu tidak merupakan bagian dari kebudayaan akan tetapi bercorak pribadi. Sosialisasi tercapai melalui komunikasi dengan anggota masyarakat lainnya. Pola kelakuan yang diharapkan dari anak terus-menerus disampaikan dalam segala situasi di mana ia terlibat. Kelakuan yang tak sesuai dikesampingkan karena menimbulkan konflik dengan lingkungan sedangkan kelakuan yang sesuai dengan norma yang diharapkan dimantapkan.Dalam interaksi remaja dengan lingkungan, lambat laun kesadaran akan dirinya diperoleh sebagai pribadi yang memiliki jati diri. Selanjutnya belajar untuk memandang dirinya sebagai obyek seperti orang lain memandang dirinya. Membayangkan kelakuan apa yang diharapkan orang lain kepadanya juga dapat diperolehnya. Selain itu juga, untuk mengatur kelakuannya 
seperti yang diharapkan orang lain kepadanya, serta dapat merasakan perbuatannya yang salah dan keharusan untuk meminta maaf juga akan diperolehnya.

Dengan menyadari dirinya sebagai pribadi ia dapat mencari tempatnya dalam struktur sosial, dapat mengharapkan konsekuensi positif bila berlakuan menurut norma-norma atau akibat negatif atas kelakuan yang melanggar aturan. Demikianlah akhirnya ia lebih mengenal dirinya dalam lingkungan sosialnya, dapat menyesuaikan kelakuannya dengan harapan masyarakat dan menjadi anggota masyarakat malalui proses sosialisasi yang dilaluinya. Jadi, menurut Sarwono, dalam interaksi sosial itu memperoleh "self concept" atau suatu konsep tentang dirinya.

Salah satu pergaulan yang pasti dialami oleh setiap siswa adalah teman sebayanya. Teman sebaya adalah lingkungan kedua setelah keluarga, yang berpengaruh bagi kehidupan individu. Terpengaruh tidaknya individu dengan teman sebaya tergantung pada persepsi individu terhadap kelompoknya, sebab persepsi individu terhadap kelompok sebayanya akan menentukan keputusan yang diambil nantinya.Kelompok sebaya menyediakan suatu lingkungan, yaitu tempat teman sebayanya dapat melakukan sosialisasi dengan nilai yang berlaku, bukan lagi nilai yang ditetapkan oleh orang dewasa, melainkan oleh teman seusianya, dan tempat dalam rangka menentukan jati dirinya, namun apabila nilai yang dikembangkan dalam kelompok sebaya adalah nilai negatif maka akan menimbulkan bahaya bagi perkembangan jiwa individu.Kuatnya pengaruh kelompok teman sebaya juga mengakibatkan melemahnya ikatan individu dengan orang tua, sekolah, norma-norma konvensional. Selain itu, banyak waktu yang diluangkan individu di luar rumah bersama teman-teman sebayanya dari pada dengan orang tuanya adalah salah satu alasan pokok pentingnya peran teman sebaya bagi individu.Peranan penting kelompok sebaya terhadap individu berkaitan dengan sikap, pembicaraan, minat, penampilan dan perilaku remaja seringkali meniru bahwa memakai model pakaian yang sama dengan anggota kelompok yang popular maka kesempatan bagi dirinya untuk diterima oleh kelompok sebaya menjadi besar.

Salah satu upaya untuk mendefinisikan penyimpangan perilaku remaja dalam arti kenakalan anak, menurut M. Gold dan J. Petronio (Dalam Sarlito) mengatakan bahwa : kenakalan anak adalah tindakan oleh seseorang yang belum dewasa yang segaja melanggar hukum dan yang diketahui oleh anak itu sendiri bahwa jika perbuatannya itu sempat diketahui oleh petugas hukum ia bisa dikenai hukuman". 
Kenakalan remaja muncul akibat terjadinya interaksi sosial diantara individu sosial dengan kelompok sebaya. Peran interaksi dengan kelompok sebaya tersebut dapat berupa imitasi, identifikasi, sugesti dan simpati yang dapat menyebabkan perlakuan menyimpang siswa.Perlakuan menyimpang yang akan timbul dari pergaulan dengan teman sebaya seperti meniru (imitasi) kenakalan yang dilakukan oleh teman sebayanya. Kenakalan remaja itu dapat berupa penyalagunaan NAPZA, Geng Motor, perkelahian, perusakan, pencurian, membolos sekolah dan lain-lain. Sementara itu sugesti bahwa kebutuhan-kebutuhan dan penggunaan NAPZA adalah remaja yang semula baik menjadi nakal. Kuatnya pengaruh kelompok sebaya yang mengarahkan remaja nakal atau tidak juga ditentukan bagaiman persepsi remaja terhadap kelompok teman sebaya tersebut.

Teman sebaya adalah tempat memperoleh informasi yang tidak didapat di dalam keluarga, tempat menambah kemampuan dan tempat kedua setelah keluarga yang mengarahkan dirinya menuju perilaku yang baik serta memberikan masukan (koreksi) terhadap kekurangan yang dimilikinya, tentu saja akan membawa dampak positif bagi remaja yang bersangkutan. Remaja memiliki kecenderungan bahwa teman sebaya adalah tempat untuk belajar bebas dari orang dewasa, belajar menyesuaikan diri dengan standar kelompok, belajar berbagi rasa, bersikap sportif, belajar, menerima dan melaksanakan tanggung jawab. Belajar berperilaku sosial yang baik dan belajar bekerjasama.Fenomena kehidupan remaja sering kita lihat dari berbagai informasi baik dari media cetak maupun media elektronik, seperti maraknya penggunaan narkoba dikalangan remaja, tawuran, sex bebas, pemerkosaan, meminum minuman keras, merokok, dan lainnya yang merugikan masyarakat. Pada saat ini kita dipertontonkan dengan berita pemerkosaan anak di bawah umur, tentu penyimpangan-penyimpangan perilaku ini sangatlah membahayakan bagi keamanan dalam bermasyarakat. Berbagai dampak dari perilaku menyimpang ini timbul dari salah satunya berasal dari pergaulan teman sebaya sehari-hari. Oleh karena itu, sebaiknya kita selalu mawas diri dalam menghindari kehidupan yang telah menyimpang.

Perilaku menyimpang yang pernah dilakukan seorang siswi pelajar asal SMK Negeri 3 Kota Padang sidimpuan seperti yang dikutip dari JPNN News Online bahwa telah terjadi aksi bunuh diri yang dilakukan seorang siswi bernama Amelia, sebelum ia meminum racun tanaman, diketahui bahwa ia telah mencuri uang milik neneknya berjumlah 1,6 Juta yang pada akhirnya luapan kekesalannya diluapkan dengan cara 
meminum racun yang mengakibatkan dirinya meninggal dunia. Contoh kasus di atas menunjukkan bahwa perilaku siswa yang menyimpang tersebut bisa saja bersumber dari pengaruh lingkungan teman sebayanya, bisa saja bersumber dari lingkungan rumahnya sendiri.

\section{METODE PENELITIAN}

\section{Definisi Operasional Variabel Penelitian}

a) Variabel Bebas

Variabel bebas adalah variabel yang mempengaruhi.Variabel bebas dalam penelitian ini adalah Teman Sebaya, dengan kode (X).

b) Variabel Terikat

Variabel terikat adalah variabel yang dipengaruhi atau yang diselidiki hubungannya.Dalam penelitian ini yang dijadikan variabel terikat adalah Perilaku Menyimpang, dengan kode (Y).

\section{Lokasi Penelitian}

Lokasi dalam penelitian ini adalah SMKSwasta Satria Binjai yang beralamat di Jalan Soekarno-Hatta Km. 19,5 Kecamatan Binjai Timur Kota Binjai. Adapun waktu pelaksanaan penelitian ini dilaksanakan pada semester ganjil tahun pelajaran $2017 / 2018$

\section{Populasi dan Sampel}

Keseluruhan dari unit yang dijadikan sebagai objek penelitian disebut populasi. Populasi merupakan jumlah keseluruhan yang dapat dijadikan sumber data yang akan diduga. Adakalanya dalam melaksanakan penelitian menjadikan keseluruhan unit subjek yang diteliti dan terkadang hanya mengambil sebagian saja dari keseluruhan objek yang diteliti sebagai dasar mengambil kesimpulan. Hal ini umumnya dilakukan karena banyaknya objek yang sedang dan akan diteliti atau berdasarkan pertimbanganpertimbangan yang lain yang logis.

Suharsimi Arikunto mengatakan "Untuk sekadar ancer-ancer maka apabila subjeknya kurang dari 100, lebih baik diambil semua sehingga penelitiannya merupakan penelitian populasi. Selanjutnya, jika jumlah subjeknya besar dapat diambil antara $10-15 \%$ atau $20-25 \%$ atau lebih.”

Jadi, berdasarkan pendapat di atas, maka sampel akan di ambil keseluruhan dari jumlah populasi,sehingga sampel pada penelitian ini berjumlah 50 siswa. 


\section{Jenis Penelitian}

Penelitian ini adalah penelitian kuantitatif. Dalam penelitian ini, variabel yang mempengaruhi disebut Independent Variable (variabel bebas) dan variabel yang dipengaruhi disebut Dependent Variable (variabel terikat)

\section{Alat Pengumpulan Data}

Untuk memperoleh data tentang pengaruh teman sebaya terhadap Perilaku Menyimpang, penulis memilih angket sebagai instrumen yang dibagikan kepada siswa responden diisi sesuai dengan pribadinya sendiri tanpa bantuan pihak lain. Angket ini berupa jawaban tertutup, yang masing-masing soal disediakan pilihan yang menjadi alternatif jawaban. Pilihan jawaban yang paling sesuai dengan yang diharapkan diberi bobot paling besar 4 (empat), pilihan jawaban yang paling tidak sesuai dengan yang diharapkan diberi bobot paling rendah 1 (satu). Dengan demikian bobot jawaban yang diberi adalah 4, 3, 2, dan 1. Bagi siswa yang tidak memberi jawaban diberi skor 0 (nol).

\section{HASIL DAN PEMBAHASAN}

Penelitian ini dimaksudkan untuk mengetahui hubungan antara dua variabel bebas,Teman Sebaya (X) denganPerilaku Menyimpang (Y). Cara yang digunakan dalam menganalisis data dilakukan dengan analisis statistik.

\section{Uji Asumsi}

\section{a. Uji Normalitas}

Untuk uji normalitas digunakan uji liliefors dengan langkah-langkah sebagai berikut :

Contoh perhitungan adalah baris pertama pada uji normalitas angket teman sebaya

1). Menyusun skor siswa dari yang terendah ke skor yang tertinggi.

2). Nilai diubah kedalam distribusi normal.

$$
Z_{i}=\frac{x i-\bar{X}}{S}=\frac{40-52}{13,93}=-0,86
$$

3). Menghitung peluang $F\left(Z_{i}\right)=P\left(Z \leq Z_{i}\right)$ dengan menggunakan daftar distribusi normal baku.

4). Menghitung proporsi $S\left(Z_{i}\right)$ 
$S\left(\mathrm{Z}_{i}\right)=\frac{f k}{N}=\frac{4}{50}=0,08$

5). Menghitung selisih $F(z i)-S(z i)$ kemudian ditentukan hargamutlaknya.

6). Mengambil harga $L$ hitung yang paling besar diantara harga mutlak (yang terbesar disebut $\mathrm{L}_{0}$ ). Untuk menerima atau menolak hipotesis.

Untuk baris seterusnya perhitungannya sama. Sehingga diperoleh :

$$
\begin{gathered}
L_{0}=0,1202 \\
\text { Dan } \\
L_{t}=\frac{0,886}{\sqrt{n}}=\frac{0,886}{\sqrt{50}}=0,1253
\end{gathered}
$$

Karena $L_{0}<L_{t}(0,1202<0,1253)$ maka dapat disimpulkan bahwa sampel berdistribusi normal.

\section{b. Uji kelinearan dan keberartian regresi sederhana $\mathrm{Y}$ atas $\mathrm{X}$}

Jumlah Kuadrat Total, yaitu:

$$
\begin{aligned}
J K_{(T)} & =\Sigma Y^{2} \\
& =178075
\end{aligned}
$$

Jumlah Kuadrat Regresi (a), yaitu:

$$
\begin{aligned}
J K_{(a)} & =\frac{\left(\sum Y\right)^{2}}{n} \\
& =\frac{(2975)^{2}}{50} \\
& =\frac{8850625}{50} \\
& =177012,5
\end{aligned}
$$

Jumlah Kuadrat Regresi (b), yaitu:

$$
\begin{aligned}
J K_{(b / a)} & =b\left\{\sum x y-\frac{\left(\sum x\right)\left(\sum y\right)}{n}\right\} \\
& =(0,21)\left\{(154600)-\frac{(2590)(2975)}{50}\right\} \\
& =(0,21)\left\{(154600)-\frac{770520}{50}\right\} \\
& =(0,21)\{(154600)-(154105)\} \\
& =(0,21)(495) \\
& =103,95
\end{aligned}
$$

Jumlah Kuadrat Residu, yaitu: 


$$
\begin{aligned}
\mathrm{JK}_{(\mathrm{res})} & =\mathrm{JK}_{(\mathrm{T})}-\mathrm{JK}_{(\mathrm{a})}-\mathrm{JK}_{(\mathrm{b} / \mathrm{a})} \\
& =178075-177012,5-103,95 \\
& =958,55
\end{aligned}
$$

Jumlah Kuadrat Error, yaitu:

$\mathrm{JK}(\mathrm{E}) \quad=\sum Y^{2}-\frac{\left(\sum Y\right)^{2}}{n_{i}}$

\section{c.Uji Validitas Tes}

Uji validitas tes ini dimaksud untuk mengetahui valid tidaknya masing-masing item soal. Uji validitas tes dalam penelitian ini menggunakan uji korelasi product moment.

$$
r_{x y}=\frac{N \sum X Y-\left(\sum X\right)\left(\sum Y\right)}{\sqrt{\left\{N \sum X^{2}-\left(\sum X\right)^{2}\right\}\left\{N \sum Y^{2}-\left(\sum Y\right)^{2}\right\}}}
$$

Keterangan :

$\begin{array}{ll}\mathrm{r}_{\mathrm{xy}} & \text { : Nilai koefisien variable } \mathrm{X} \text { dan } \mathrm{Y} \\ \mathrm{N} & \text { : Jumlah responden penelitian } \\ \sum \mathrm{X} & \text { : Jumlah skor variabel } \mathrm{X} \\ \sum \mathrm{Y} & \text { : Jumlah skor variabel } \mathrm{Y} \\ \sum \mathrm{XY} & \text { : Jumlah perkalian skor variabel } \mathrm{X} \text { dan } \mathrm{Y} \\ \sum \mathrm{X}^{2} & \text { : Jumlah kuadrat skor Variabel } \mathrm{X} \\ \sum \mathrm{Y}^{2} & \text { : Jumlah kuadrat skor variabel } \mathrm{Y}\end{array}$

\section{Hasil Analisis}

Pengujian hipotesis dilakukan dengan tujuan untuk mengetahui tingkat signifikasi antara hubungan persepsi tentang layanan Bimbingan dan Konseling dengan minat berkonsultasi. Untuk memperoleh nilai $\mathrm{r}$ atau korelasi antara variabel $\mathrm{X}$ (Peran guru Bimbingan dan Konseling) dengan Variabel Y (Minat Berkonsultasi Siswa) maka dianalisa menggunakan program SPSS.

Dari hasil perhitungan rxy menggunakan program SPSS 18,0Dari perhitungan tersebut dapat diketahui thitung $=2,881$ dengan taraf sinifikan $0,05 / 2=0,025, \mathrm{n}-1$ yaitu 37-1 = 36. Selanjutnya Hipotesis diterima apabila perhitungan dari jumlah thitung lebih besar pada perhitungan jumlah ttabel, kemudian berdasarkan daftar harga ttabel yang telah ditetapkan dengan 0,025 ttabel $=2,028$. berdasarkan hal tersebut , maka dapat dilihat bahwa harga thitung lebih besar dari pada ttabel atau 2,881 > 
2,028, sehingga dapat disimpulkan bahwa hipotesis dari penelitian ini dapat diterima dan signifikan .

Berdasarkan hasil-hasil yang telah diperoleh dalam penelitian ini, maka dapat disimpulkan hal-hal sebagai berikut Terdapat Hubungan positif antara peran guru bimbingan dan konseling dengan minat berkonsultasi. Hasil ini di buktikan dengan koefisien korelasi $r_{x y}=0,653>0,325$.

\section{Uji Hipotesis}

Untuk melihat ada atau tidaknya Pengaruh Teman Sebaya Terhadap Perilaku Menyimpang Siswa Kelas X SMK Swasta Satria Binjai Tahun Pelajaran 2017/2018 dengan menggunakan rumus sebagai berikut:

$$
r=\frac{N \sum X Y-\left(\sum X\right)\left(\sum Y\right)}{\sqrt{\left\{N \sum X^{2}-\left(\sum X\right)^{2}\right\}\left\{N \sum Y^{2}-\left(\sum Y\right)^{2}\right\}}}
$$

Hipotesis yang akan diuji adalah :

$\mathrm{H}_{0}: \mathrm{r}=0$

$\mathrm{H}_{\mathrm{a}}: \mathrm{r} \neq 0$

Berdasarkan hasil perhitungan hasil angket diperoleh harga-harga sebagai berikut:

$$
\begin{array}{llllll}
\Sigma X & =2590 & \Sigma X Y & =154600 & \Sigma Y^{2} & =178075 \\
\Sigma X^{2} & =136500 & \Sigma Y & =2975 & n & =50
\end{array}
$$

$r=\frac{N \sum X Y-\left(\sum X\right)\left(\sum Y\right)}{\sqrt{\left(N \sum X^{2}-\left(\sum X\right)^{2}\right)\left(N\left(\sum Y^{2}\right)-\left(\sum Y\right)^{2}\right)}}$

$r=\frac{50(154600)-(2590)(2975)}{\sqrt{\left(50(136500)-(2590)^{2}\right)\left(50(178075)-(2975)^{2}\right.}}$

$r=0,314$

$d f=n-2=50-2=48$

$\mathrm{r}_{0,05}=0,284$

Pada taraf signifikan $5 \%$ di dapat $r_{\text {tabel }}=0,284$. Karena $r_{\text {hitung }}>r_{\text {tabel }}(0,314>$ 0,284), maka dapat disimpulkan $\mathrm{H}_{\mathrm{a}}$ diterima, yaitu terdapat Pengaruh Teman Sebaya Terhadap Perilaku Menyimpang Siswa Kelas X SMK Swasta Satria Binjai Tahun Pelajaran 2017/2018. 


\section{KESIMPULAN}

Setelah penelitian yang dilakukan pada siswa kelas X SMK Swasta Satria Binjai Tahun Pelajaran 2017/2018 dengan jumlah sampel sebesar 50 siswa. Penelitian ini menggunakan sistem angket teman sebaya dan angket perilaku menyimpang sebagai instrumen pengumpul datanya, maka dapat disimpul kan bahwa terdapat pengaruh teman sebaya terhadap perilaku menyimpang siswa kelas X SMK Swasta Satria Binjai Tahun Pelajaran 2017/2018.

\section{DAFTAR PUSTAKA}

Arifin, Tatang M. Menyusun Rencanan Penelitian. Jakarta:Grafindo. 1998.

Arikunto, Suharsimi.Prosedur Penelitian. Jakarta, RinekaCipta, 2009.

Hadi, Sutrisno. Metodologi Research. Bandung : Andi Offset. 1989.

Karono, Katini. PatologiSosial II: Kenakalan Remaja. Jakarta: Raja GrafindoPersada. 2005.

Kartono. Psikologi Sosial Untuk Manajemen, Perusahaan dan Industri. Jakarta: Raja Grafindo Persada. 1994.

Mappiare,A. Psikologi Remaja. Surabaya : Usaha Nasional.

Riduan. Belajar Mudah Penelitian. Bandung : Alfabet, 2010.

Sarwono,Sarlito W. Psikologi Remaja. Jakarta : Raja Grafindo Persada, 2013.

Sarwono. Psikologi Sosial. Jakarta : Balai Pustaka. 2001.

Santrock,WJ. Adolescence : Perkembangan Remaja. Jakarta : Erlangga. 2003.

Sudarsono.Kenakalan Remaja. Jakarta: RinekaCipta.2004.

Santrock, John W. AdolescancePerkembangan Remaja.Jakarta: Erlangga. 2003.

Sugiono. Meode Penelitian Kuantitatif dan Kualitatif. Bandung : Alfabet, 2013.

Sarwono,Jhonatan. Metode Penelitian Kualitatif dan Kuantitatif. Yogyakarta;Graha Ilmu,2006.

Sudjana, Nana.MetodeStatistik.Bandung :Tarsito,2007.

Usman, Husain dan Setyady, Purnomo. Penelitian Sosial. Jakarta : Buki aksara. 2000.

Willis, Sofyan S. Remajadan Masalahnya. Bandung: Alfabeta. 2000. 